\title{
The EFFECTS OF Disclosure REGULATION OF AN INNOVATIVE FIRM
}

\author{
JOS JANSEN \\ CESIFO WORKING PAPER NO. 1459 \\ CATEGORY 9: INDUSTRIAL ORGANISATION \\ APRIL 2005
}
An electronic version of the paper may be downloaded
- from the SSRN website:
wWw.SSRN.com
- from the CESifo website:
www.CESifo.de




\title{
THE EFFECTS OF Disclosure RegULATION OF AN INNOVATIVE FIRM
}

\begin{abstract}
A firm actively manages its rival's beliefs by disclosing and concealing information on the size of its process innovation. The firm's disclosure strategy results from the trade-off between two effects on product market incentives. First, the firm's competitor learns that the firm is efficient, which discourages the competitor. Second, the competitor becomes more efficient himself, since he can expropriate part of the disclosed knowledge, which encourages him. I characterize the equilibrium disclosure strategies for any knowledge spillover in a simple Cournot duopoly model, and illustrate the results graphically. Moreover, I compare the strategic disclosure equilibria with equilibria under non-strategic disclosure.
\end{abstract}

JEL Code: D82, L23, O31.

Keywords: process innovation, Cournot competition, strategic substitutes, information disclosure, knowledge spillovers.

\author{
Jos Jansen \\ Social Science Research Center Berlin (WZB) \\ Research Unit MP2 (CIC) \\ Reichpietschufer 50 \\ 10785 Berlin \\ Germany \\ jansen@wz-berlin.de
}

I am especially grateful to Patrick Bolton, Eric van Damme, Sanjeev Goyal, and Dan Kovenock for discussions. I also thank the editor Jay Pil Choi, an anonymous referee, Marco Haan, Paul Heidhues, Johan Lagerlöf, Luca Lambertini, Pedro Perreira, Fréderic Pivetta, Dolf Talman, and seminar participants at CORE (Louvain-la-Neuve), IUI (Stockholm), UCM (Madrid), UAB (Barcelona), MERIT (Maastricht), and the CESifo Venice Summer Institute 2004 for helpful comments. The hospitality and support of MPSE (Université de Toulouse 1, France), and the Department of Economics at Princeton University are gratefully acknowledged. Naturally, all errors are mine. 


\section{Introduction}

In many industries firms make announcements about their innovations. Preannouncements are made in e.g. the information technology, biotechnology, pharmaceutical, and car industries. Communication between firms has potential negative and positive effects on welfare.

Among the potential negative effects of preannouncements is the possibility of predation. For example, it is often claimed that Microsoft is using preannouncements of its products (e.g. operating system upgrades, game console) to drive competition out of its market. ${ }^{1}$ Disclosing good news about one's own new product or production process while hiding bad news, may discourage rivals to supply a competing product. The potential anti-competitive effects of Microsoft's product preannouncements were discussed during the 1994-95 licensing court case against Microsoft (e.g. see United States v. Microsoft, Civil Action No. 94-1564). Although the judge recognized that preannouncements may have anti-competitive effects, no restrictions were placed on Microsoft's announcements. ${ }^{2}$

Second, firms can use communication to facilitate collusion. Detection of deviations from collusive agreements is easier when firms frequently share information related to their strategies. Kühn and Vives (1995) and Kühn (2001) carefully analyze the conditions under which communication between firms is correlated with collusion, and is unlikely to have efficiency benefits. From these conditions, which are based on economic theory, experiments and case studies, the papers derive simple policy rules to fight collusion by restricting communication between firms.

My paper studies the effects of imposing a simple restriction on communication between firms: the prohibition of precommitment to information sharing rules. Firms may attempt to precommit to disclose or conceal their information through the es-

\footnotetext{
${ }^{1}$ See e.g. Lopatka and Page (1995), Prentice (1996), Shapiro (1996), and Shapiro and Varian (1999). An anacdotical report on Microsoft's strategies is presented in Wallace and Erickson (1992).

${ }^{2}$ Another case in which some effects of product announcements were discussed occurred in the period 1987-1991 when shareholders of Apple Computer brought securities fraud charges against the company. Apple's preannouncement of its Lisa computer and Twiggy disk drive and subsequent extensive delay in delivery was alleged to violate Section 10(b) and Rule 10b-5 of the 1934 US Securities Exchange Act (e.g. see Prentice and Langmore, 1994). The case was settled out of court.
} 
tablishment of a trade association, or the organization of frequent trade fares. If precommitment is prohibited, then a firm can only make strategic, unilateral disclosure choices, e.g. through the publication in scientific journals.

More drastic restrictions on communication between innovative firms may yield welfare losses, since the following two potential efficiency gains would be foregone. First, communication between competing firms may enhance allocative efficiency, since it facilitates more efficient decision-making in the product market. Kühn and Vives (1995) give an overview of the potential positive profit and welfare effects. The assumptions of my model are such that positive profit and welfare effects emerge from communication.

Second, a firm's preannouncement can also reveal some valuable information about the innovation's contents to the competitor. When knowledge about the contents of an innovation is revealed to a rival firm after disclosure, this enables the rival firm to imitate, and become more efficient himself. The improvement of productive efficiency resulting from this expropriation effect may be yet another reason for an antitrust authority not to prohibit communication between innovative firms.

A preannouncing firm faces the following trade-off. On the one hand, the firm creates a strategic advantage by revealing it is an efficient, "aggressive" Cournot competitor. On the other hand, the disadvantage of disclosure is that some of the contents of the innovation spills over to the competitor, which enables him to catch up. This expropriation effect, which is central in most patent design literature (e.g. see Scotchmer, 1991), reduces a firm's incentive to disclose its innovation. While the strategic effect gives firms an incentive to disclose innovations, the expropriation effect encourages concealment of information. Gertner (1998, p. 608) makes a related observation:

"Firm 1 may wish to convince Firm 2 that it has low costs to induce Firm 2 to exit or produce less. If the only way to certify this information is to reveal technological secrets that Firm 2 may be able to appropriate, disclosure is unlikely." 
This paper illustrates the effect of this trade-off on the innovative firm's disclosure strategy, and on the firms' production incentives.

In particular, I compare the expected profit of Cournot duopolists under precommitment with the expected profit under strategic disclosure. Under precommitment the disclosure rule of a firm is fixed before the firm learns the size of its innovation. Under strategic disclosure an innovative firm learns the size of its process innovation, and chooses strategically whether to disclose this information to its rival.

The paper, together with a companion paper Jansen (2005), attempts to contribute to the literature on spillovers in oligopoly, and the literature on strategic information disclosure. Whereas the current paper gives a simple graphical analysis of a model with one-sided asymmetric information about discrete types, the companion paper (Jansen, 2005) studies the problem of information disclosure among innovative firms with two-sided asymmetric information about a continuum of types.

The literature on the effects of spillovers in oligopoly is extensive, see e.g. d'Aspremont and Jacquemin (1988), Kamien et al. (1992), and Katsoulacos and Ulph (1998). My contribution to this literature is to study the effects of spillovers in a setting with asymmetric information. Anton and Yao (2003, 2004) study information disclosure incentives of competing, innovative firms. These papers focus on separating equilibria where, although firms do not disclose all information, the disclosed information is a perfect signal of the firm's efficiency. ${ }^{3}$ The amount of knowledge that is expected to spill over to the rival determines a firm's disclosure strategy. The size of the knowledge spillover plays an important role in my analysis too. But in contrast to Anton and Yao's important results, I obtain equilibria that need not be fully revealing to firms. An important difference between this paper and Anton and Yao is that I study disclosure incentives of a firm with an indivisible innovation. Therefore, the only choice of an innovative firm in this paper is between disclosure and concealment of all information. A firm in Anton and Yao chooses how much information to disclose.

\footnotetext{
${ }^{3}$ Also Bayus et al. (2001) study a signalling model of preannouncements. In contrast to Anton and Yao and my paper, the innovative firm attempts to deter entry by sending costly messages, where the signal cost is exogenous.
} 
Furthermore, I perform profit and welfare analyses, which are absent in Anton and Yao.

Recently, Gill (2004) analyzed a related model, where an innovative firm strategically discloses information related to its innovative efficiency and the size of the innovation. This paper differs in several respects from mine. Most importantly, Gill studies R\&D incentives, while I study product market incentives. On a technical level Gill analyzes a model with discrete actions and a continuous types space, while the present paper does the reverse, i.e. a continuous action space and a discrete types space. That is, whereas Gill studies entry deterrence strategies, I focus on entry accommodation strategies. Also Jansen (2004) studies a related problem. But, in contrast to the present paper, Jansen focuses on R\&D incentives, and analyzes a model with perfectly correlated types. This yields different disclosure incentives. Both Gill and Jansen obtain concealment of information for some parameter values.

Strategic preannouncements of innovations, have been analyzed in the fields of law, marketing, and economics. One of the first papers to point to the potential strategic implications of preannouncements is Ordover and Willig (1981). Among the contributions in economics are e.g. Farrell and Saloner (1986), Lopatka and Page (1995), Levy (1997), Haan (2003), Dranove and Gandal (2003), Gerlach (2004), and Choi et al. (2004). These papers typically study the effects of preannouncements on consumers' beliefs and demand. The present paper focuses on the direct, strategic effects of information disclosure on a firm's competitor, and the potential expropriation of technological knowledge by a competitor.

Thereby the paper intends to contribute to the literature on information sharing in oligopolistic markets. Most economics literature has focused on non-strategic information sharing. ${ }^{4}$ My contribution to papers such as Fried (1984), Gal-Or (1986), and Shapiro (1986) is to study the effects of knowledge spillover on information sharing incentives. I also give graphical illustrations of the main results. Moreover, I study strategic disclosure incentives, and compare them with the incentives to precommit

\footnotetext{
${ }^{4}$ For instance, Kühn and Vives (1995), Raith (1996), and Vives (1999) contain recent surveys. Jin (1995) studies the effects of precommitment to announcements about product quality.
} 
to disclosure rules.

Strategic information disclosure is extensively studied in the accounting literature. ${ }^{5}$ But in this literature precommitment to disclosure rules is not often analyzed. An important result in strategic disclosure analysis is the so-called "unraveling result". When it is known that the sender of information is informed, and there are no costs of verification or disclosure, then the sender can often not do better than disclose his information, given skeptical equilibrium beliefs of the receiver. Papers by e.g. Grossman (1981), Milgrom (1981), Milgrom and Roberts (1986), and Okuno-Fujiwara et al. (1990) study this result. Okuno-Fujiwara et al. give sufficient conditions under which the unraveling result applies. The sufficient condition that is violated in my model is "positive-monotonicity of best response functions." This violation, which emerges in industries with positive knowledge spillovers, may cause a break-down of the unraveling result, as I demonstrate below.

The paper is organized as follows. In the next section I describe the model. The third section discusses the equilibrium outputs and profits when the innovative firm precommits to either disclose all cost information or none. Section 4 gives the equilibrium outputs and disclosure choices when the innovative firm strategically discloses information, and I compare expected profits under precommitment with those under strategic disclosure. Section 5 briefly discusses some economic policy implications of the analysis. Finally, section 6 concludes the paper. The proofs of the paper's main propositions are relegated to the Appendix.

\section{The Model}

Two firms, firms $i$ and $n$, produce homogeneous goods. Firm $i$, the innovative firm, has private information about its unit production cost, $\theta_{i}$, which is either low, $\theta_{i}=\underline{\theta}$, with probability $p$, or high, $\theta_{i}=\bar{\theta}$, with probability $1-p$, where $0 \leq \underline{\theta}<\bar{\theta}$ and $0<p<1$. Firm $n$ is not innovative, and has a high unit production cost $\theta_{n}=\bar{\theta}$. Firm $n$ 's marginal cost is common knowledge.

\footnotetext{
${ }^{5}$ For recent surveys on discretionary disclosure of proprietary information in the accounting literature, see e.g. Dye (2001), and Verrecchia (2001).
} 
After firm $i$ learns its cost, it makes a disclosure choice. Firm $i$ with cost $\theta_{i}$ chooses the probability of disclosure $\delta\left(\theta_{i}\right)$, i.e. with probability $\delta\left(\theta_{i}\right)$ the firm reveals its cost truthfully, while with probability $1-\delta\left(\theta_{i}\right)$ the firm conceals and sends an uninformative message, $\varnothing$. That is, firm $i$ 's information is verifiable. Denote firm $i$ 's realized disclosure $D$, where $D \in\left\{\theta_{i}, \varnothing\right\}$.

Finally, firms choose output levels of a homogeneous good (Cournot competition). Firm $i$ chooses output level $x_{i} \geq 0$ at cost $\theta_{i} x_{i}$. Firm $n$ 's unit cost, $C(D, \kappa)$, depends as follows on the technology disclosed by firm $i$. If firm $i$ discloses a low cost, then part of this knowledge, $\kappa$, spills over to firm $n$. In all other cases, i.e. firm $i$ discloses a high cost or nothing, no useful knowledge spills over, i.e.

$$
C(D, \kappa)=\left\{\begin{array}{l}
\kappa \underline{\theta}+(1-\kappa) \bar{\theta}, \text { if } D=\underline{\theta} \\
\bar{\theta}, \text { otherwise }
\end{array}\right.
$$

The inverse demand for the good is linear, i.e. $P(X)=A-X$, with $X \equiv x_{1}+x_{2}$. Given cost $\theta_{j}$, firm $j$ 's expected profit is:

$$
\pi_{j}\left(\mathbf{x} ; \theta_{j}\right)=\left(A-\theta_{j}-X\right) x_{j}
$$

with $\mathbf{x} \equiv\left(x_{i}, x_{n}\right)$ and $j \in\{i, n\}$. Firms are risk-neutral. I solve the game backwards, i.e. I consider Bayes perfect equilibria.

\section{Precommitment Regimes}

In this section I study two standard disclosure regimes. In the first regime firm $i$ precommits to disclose its information $\theta_{i}$. In the second regime the innovative firm precommits to conceal its information. Such ex ante precommitment could be obtained through the establishment of a trade association or the organization of frequent trade fares.

\subsection{Full Disclosure}

When firm $i$ precommits to disclose its marginal cost, i.e. $(\delta(\underline{\theta}), \delta(\bar{\theta}))=(1,1)$, firms base their supply decision on their relative costs. The first order conditions of each 
firm's profit maximization gives the following best response functions of firm $i$ and $n$, respectively:

$$
\begin{aligned}
x_{i}\left(x_{n} ; \theta_{i}\right) & =\frac{1}{2}\left(A-\theta_{i}-x_{n}\right), \text { and } \\
x_{n}\left(x_{i} ; C\left(\theta_{i}, \kappa\right)\right) & =\frac{1}{2}\left(A-C\left(\theta_{i}, \kappa\right)-x_{i}\right) .
\end{aligned}
$$

Derivation of the equilibrium outputs under full disclosure gives the following:

$$
\begin{aligned}
x_{i}^{d}\left(\theta_{i} ; \kappa\right) & =\frac{1}{3}\left(A-2 \theta_{i}+C\left(\theta_{i}, \kappa\right)\right), \text { and } \\
x_{n}^{d}\left(\theta_{i} ; \kappa\right) & =\frac{1}{3}\left(A-2 C\left(\theta_{i}, \kappa\right)+\theta_{i}\right),
\end{aligned}
$$

and equilibrium profit $\pi_{j}^{d}\left(\theta_{i} ; \kappa\right)=x_{j}^{d}\left(\theta_{i} ; \kappa\right)^{2}$, with $\theta_{i} \in\{\underline{\theta}, \bar{\theta}\}$ and $j \in\{i, n\}$.

First, if no knowledge spills over, $\kappa=0$, then $C\left(\theta_{i} ; 0\right)=\bar{\theta}$ for any $\theta_{i}$. The extreme case of zero knowledge spillover would be relevant in industries where firm $n$ is not allowed (e.g. through perfect and infinitely strong intellectual property rights), or not able (e.g. due to a lack of technological expertise) to imitate the efficient technology $\underline{\theta}$. The equilibrium outputs are illustrated in Figure 1 below. Curve $x_{n}\left(x_{i} ; \bar{\theta}\right)$ is firm $n$ 's

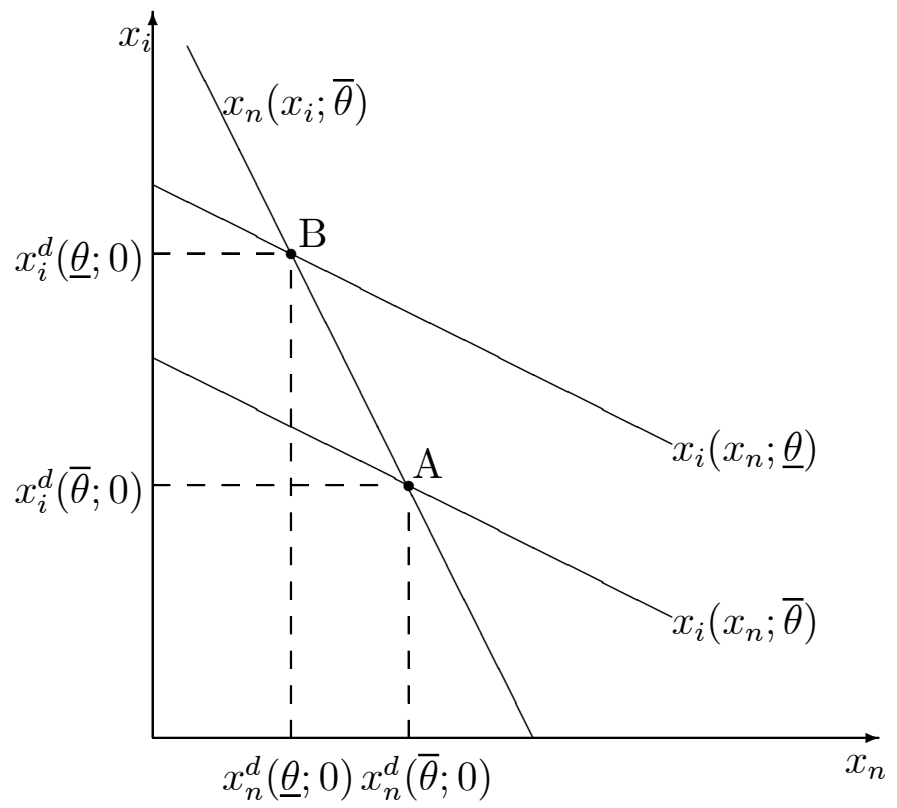

Figure 1: Full Disclosure Output $(\kappa=0)$

best response curve, as in (3.2). The curve $x_{i}\left(x_{n} ; \theta_{i}\right)$ is the best response curve of firm 
$i$ with $\operatorname{cost} \theta_{i}$ for $\theta_{i} \in\{\underline{\theta}, \bar{\theta}\}$, as in (3.1). A reduction of firm $i$ 's cost shifts firm $i$ 's best response curve outwards. That is, for any given output $x_{n}$ firm $i$ supplies relatively more of the good if it is efficient. Hence, firm $i$ 's equilibrium outputs decrease in its cost, $\theta_{i}$, while firm $n$ 's output increases in $\theta_{i}$. In other words, outputs can be ranked as follows: $x_{n}^{d}(\underline{\theta} ; 0)<x_{n}^{d}(\bar{\theta} ; 0)=x_{i}^{d}(\bar{\theta} ; 0)<x_{i}^{d}(\underline{\theta} ; 0)$. The output changes after a reduction of $\theta_{i}$ are illustrated in Figure 1 by moving from point $\mathrm{A}$ to $\mathrm{B}$.

Second, if all knowledge spills over from the innovative firm to its competitor, $\kappa=1$, firm $n$ 's cost reduces to: $C\left(\theta_{i}, 1\right)=\theta_{i}$. This extreme case would emerge if no intellectual property rights exist and firm $n$ can imitate the efficient technology at zero cost. I illustrate this case in Figure 2 below. As in Figure 1, the curve $x_{i}\left(x_{n} ; \theta_{i}\right)$ is

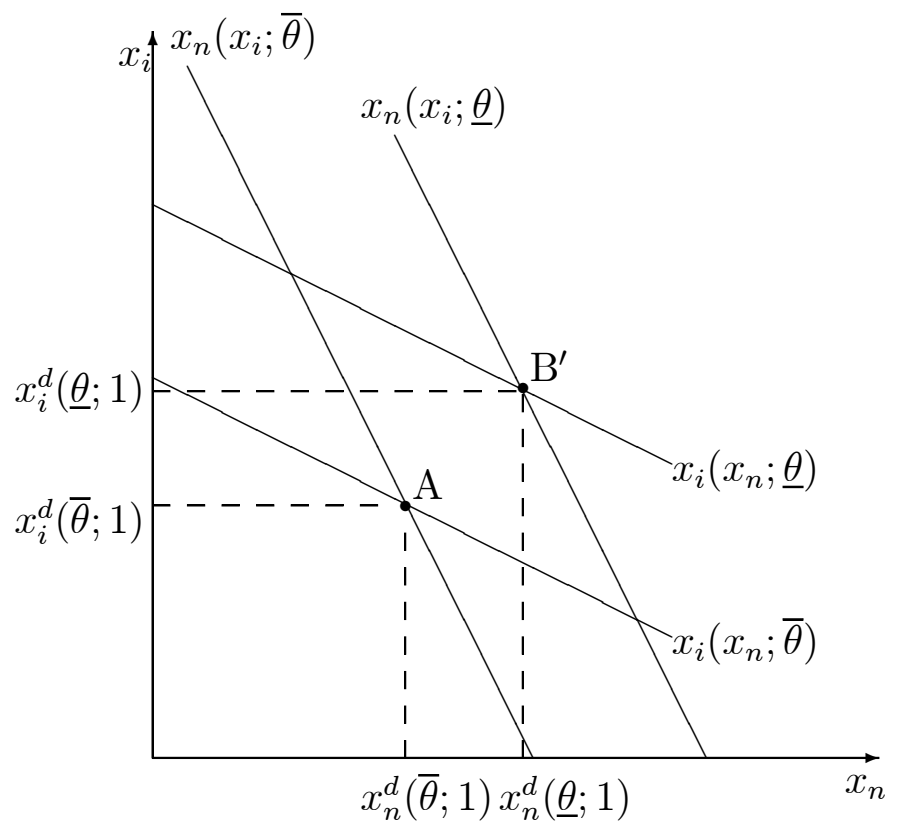

Figure 2: Full Disclosure Output $(\kappa=1)$

the best response curve of firm $i$ with $\operatorname{cost} \theta_{i}$. A cost reduction for firm $i$ now shift out the best response curves of both firms. Firm $n$ 's best response curve shifts out from $x_{n}\left(x_{i} ; \bar{\theta}\right)$ to $x_{n}\left(x_{i} ; \underline{\theta}\right)$ after disclosure of $\theta_{i}=\underline{\theta}$ through the knowledge spillover. Notice that this case is identical to a model where firms have a common cost parameter. The equilibrium outputs are symmetric, since firms have identical costs, and firms supply more output when they are efficient, i.e. $x_{j}^{d}(\underline{\theta} ; 1)>x_{j}^{d}(\bar{\theta} ; 1)$ for $j \in\{i, n\}$. This output expansion is illustrated by moving from point $\mathrm{A}$ to point $\mathrm{B}^{\prime}$ in Figure 2. 
Finally, in the intermediate cases, with spillover $0<\kappa<1$, I obtain the following comparative statics results. An increase of the knowledge spillover shifts firm $n$ 's best response curve outwards (to the right) after firm $i$ discloses $\underline{\theta}$. Hence, an increase of the knowledge spillover increases firm $n$ 's equilibrium output, $\partial x_{n}^{d}(\underline{\theta} ; \kappa) / \partial \kappa>0$, and decreases firm $i$ 's output, $\partial x_{i}^{d}(\underline{\theta} ; \kappa) / \partial \kappa<0$. These comparative statics results have consequences for later analyses.

\subsection{Full Concealment}

When firm $i$ precommits to conceal all its information, i.e. $(\delta(\underline{\theta}), \delta(\bar{\theta}))=(0,0)$, then no information spills over to firm $n$, and $C(\varnothing, \kappa)=\bar{\theta}$ for any $\kappa$. Firms choose their output levels such that firm $i$ 's best response is as in (3.1) for $\theta_{i} \in\{\underline{\theta}, \bar{\theta}\}$, and firm $n$ 's best response is:

$$
x_{n}\left(x_{i}\right)=\frac{1}{2}\left(A-\bar{\theta}-E\left\{x_{i}\left(\theta_{i}\right)\right\}\right) .
$$

Solving for the equilibrium gives the following outputs:

$$
\begin{aligned}
x_{i}^{o}\left(\theta_{i}\right) & =\frac{1}{3}\left(A-2 \theta_{i}+\bar{\theta}\right)+\frac{1}{6}\left(\theta_{i}-E\left\{\theta_{i}\right\}\right), \\
x_{n}^{o} & =\frac{1}{3}\left(A-2 \bar{\theta}+E\left\{\theta_{i}\right\}\right),
\end{aligned}
$$

with $\theta_{i} \in\{\underline{\theta}, \bar{\theta}\}$. The equilibrium outputs are illustrated in Figure 3 below. As in the previous subsection, $x_{n}\left(x_{i} ; \bar{\theta}\right)$ and $x_{i}\left(x_{n} ; \theta_{i}\right)$ are the best response curves of firm $n$ and firm $i$ with cost $\theta_{i}$, respectively. The curve $E\left[x_{i}\left(x_{n} ; \theta_{i}\right)\right]$ gives the expected best response of firm $i$ to any output chosen by firm $n$. The intersection of firm $n$ 's best response curve with firm $i$ 's expected best response gives firm $n$ 's equilibrium output $x_{n}^{o}$. The best response of firm $i$ with $\operatorname{cost} \theta_{i}$ to output $x_{n}^{o}$ is firm $i$ 's equilibrium output $x_{i}^{o}\left(\theta_{i}\right)$ for $\theta_{i} \in\{\underline{\theta}, \bar{\theta}\}$. Again, the expected profits are: $\pi_{i}^{o}\left(\theta_{i}\right)=x_{i}^{o}\left(\theta_{i}\right)^{2}$ and $\pi_{n}^{o}=\left(x_{n}^{o}\right)^{2}$.

The comparison between the firms' equilibrium outputs under full concealment gives: $x_{n}^{o}<x_{i}^{o}(\bar{\theta})<x_{i}^{o}(\underline{\theta})$. Firm $n$ expects a relatively more efficient competitor, and therefore sets the lowest output. The equilibrium outputs are such that point D (C) in Figure 3 is reached if firm $i$ is efficient (respectively, inefficient). 


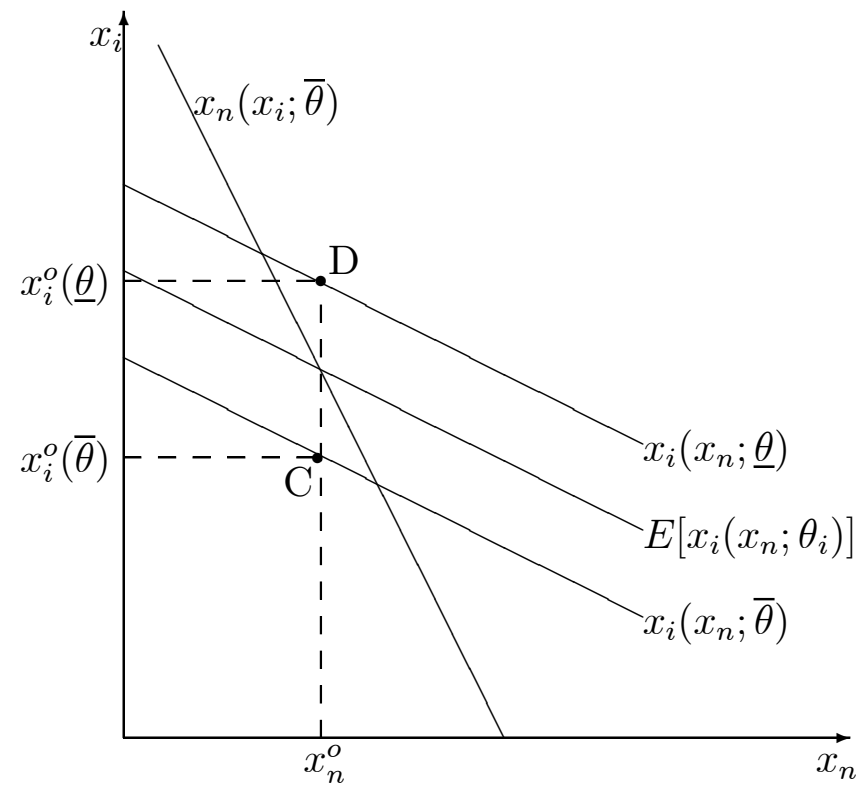

Figure 3: Full Concealment Output

If no knowledge spills over from the innovative firm to the competitor, then the ex ante expected outputs under full disclosure and full concealment are identical, i.e. $E\left\{x_{i}^{d}\left(\theta_{i} ; 0\right)\right\}=E\left\{x_{i}^{o}\left(\theta_{i}\right)\right\}=\frac{1}{3}\left(A-2 E\left\{\theta_{i}\right\}+\bar{\theta}\right)$, and $E\left\{x_{n}^{d}\left(\theta_{i} ; 0\right)\right\}=x_{n}^{o}$. For a positive spillover firm $i$ 's expected output under full disclosure is smaller than under full concealment, and the reverse holds for firm $n$. These observations are useful for the profit analysis in the next subsection.

\subsection{Profit Comparison}

The firms' equilibrium output levels determine the firms' expected equilibrium profits. Firm $j$ 's ex ante expected profits under full disclosure and full concealment are:

$$
\begin{aligned}
\Pi_{j}^{d}(\kappa) & =p x_{j}^{d}(\underline{\theta} ; \kappa)^{2}+(1-p) x_{j}^{d}(\bar{\theta} ; \kappa)^{2}, \\
\Pi_{i}^{o} & =p x_{i}^{o}(\underline{\theta})^{2}+(1-p) x_{i}^{o}(\bar{\theta})^{2} \text { and } \Pi_{n}^{o}=\left(x_{n}^{o}\right)^{2},
\end{aligned}
$$

respectively, with $j \in\{i, n\}$. The expected profit under full disclosure is an increasing function of the output levels under full disclosure, and outputs are monotonic in the spillover. Consequently, the expected equilibrium profits are monotonic functions of the knowledge spillover, i.e. $d \Pi_{j}^{d}(\kappa) / d \kappa=2 p \cdot x_{j}^{d}(\underline{\theta} ; \kappa) \cdot \partial x_{j}^{d}(\underline{\theta} ; \kappa) / \partial \kappa$ where $\partial x_{j}^{d}(\underline{\theta} ; \kappa) / \partial \kappa$ 
does not change sign for $j \in\{i, n\}$. In particular, firm $i$ 's expected profit is decreasing in the knowledge spillover, while firm $n$ 's expected profit is increasing in the spillover.

If no knowledge spills over from firm $i$ to $n(\kappa=0)$, the expected equilibrium outputs under full disclosure and full concealment are identical. Consequently, the comparison of expected profits is similar to the comparison of the variances of the firms' outputs. Figure 4 below combines Figures 1 and 3. As illustrated in this figure,

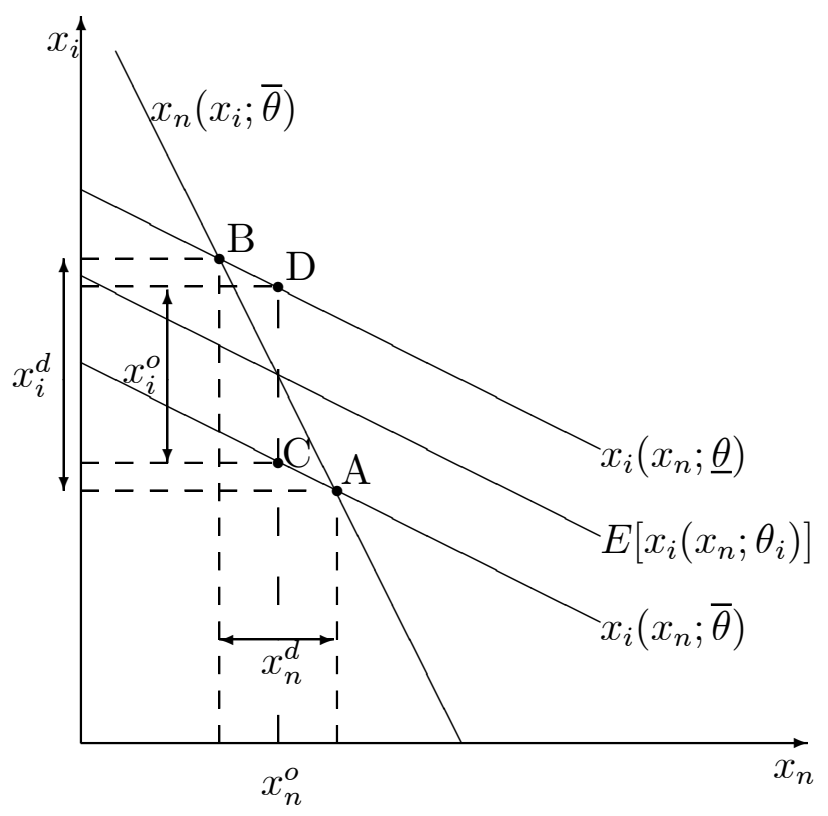

Figure 4: Precommitment Profits $(\kappa=0)$

the variance of firm $n$ 's output is clearly greatest under full disclosure. Whereas the variance of firm $n$ 's output under full concealment is zero, the variance of firm $n$ 's output under full disclosure is greater than zero. Similarly, firm $i$ 's output variance is greatest under full disclosure, as suggested by Figure 4. Consequently, both firms expect the highest profits under full disclosure. That is, if firm $i$ can precommit to full disclosure, it will do so. This result is a special case of results by Fried (1984), Gal-Or (1986), and Shapiro (1986). My contribution here is to illustrate the result graphically in a simple model. Furthermore, I show below how this result changes by the introduction of a knowledge spillover.

If all knowledge spills over $(\kappa=1)$ after disclosure, then the ex ante profit comparison is determined by the comparison of equilibrium outputs. Figure 5 below combines 
Figures 2 and 3. Disclosure has the following effects on firm $i$ 's output. If firm $i$ is

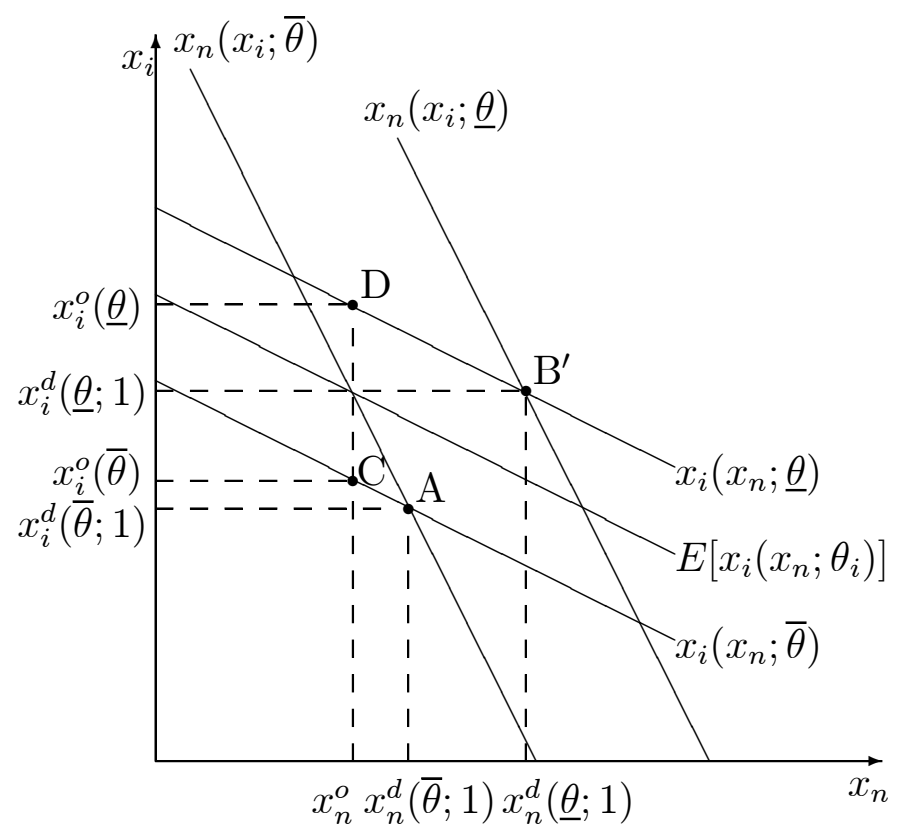

Figure 5: Precommitment Profits $(\kappa=1)$

inefficient, then firm $i$ is perceived as less "aggressive" after disclosure of $\theta_{i}=\bar{\theta}$. Disclosure results in a higher output by firm $n$, and consequently a lower output by firm $i$, than after concealment. For efficient firm $i$ the following trade-off emerges. On the one hand, firm $i$ 's expected best response curve after disclosure is above firm $i$ 's expected curve after concealment. Hence, after disclosure firm $n$ expects a more "aggressive" competitor, which gives it an incentive for output reduction. On the other hand, disclosure of $\theta_{i}=\underline{\theta}$ makes firm $n$ a more "aggressive" competitor since all knowledge spills over, i.e. firm $n$ 's best response function shifts outward after disclosure. The former effect gives firm $i$ an incentive to expand its output, but the latter effect gives an incentive to reduce firm $i$ 's output. The latter effect outweighs the former effect, as illustrated in Figure 5. Hence, firm $i$ supplies more, while firm $n$ supplies less, under full concealment than under full disclosure, i.e. $x_{i}^{o}\left(\theta_{i}\right)>x_{i}^{d}\left(\theta_{i} ; 1\right)$ while $x_{n}^{o}<x_{n}^{d}\left(\theta_{i} ; 1\right)$ for any $\theta_{i}$. Consequently, firm $i$ has a higher expected profit under full concealment, whereas firm $n$ has higher profits under full disclosure. ${ }^{6}$

\footnotetext{
${ }^{6}$ Alternatively, the profit result for firm $n$ follows immediately from the fact that for $\kappa=0$ $\Pi_{n}^{d}(0)>\Pi_{n}^{o}$, and $d \Pi_{n}^{d}(\kappa) / d \kappa>0$ for all $\kappa$.
} 
Finally, for intermediate knowledge spillovers, the profit comparison is determined by a trade-off between the effects above. Using monotonicity and continuity of the expected profit functions, the proof of the following proposition is straightforward.

Proposition 1 A critical knowledge spillover, $\kappa^{*}$ with $0<\kappa^{*}<1$, exists such that firm i's expected profit is greatest under full disclosure iff $\kappa<\kappa^{*}$, i.e. $\Pi_{i}^{d}(\kappa) \gtreqless \Pi_{i}^{o}$ iff $\kappa \lesseqgtr \kappa^{*}$. Moreover, firm $n$ expects always greater profits under full disclosure, i.e. $\Pi_{n}^{d}(\kappa)>\Pi_{n}^{o}$ for any $\kappa$.

This result qualifies previous results in the literature on information sharing in oligopoly, see e.g. Fried (1984), Gal-Or (1986), and Shapiro (1986). The innovative firm's incentive to precommit to share its information is robust to the introduction of a sufficiently small knowledge spillover. But if the knowledge spillover grows beyond a critical value $\kappa^{*}$, the innovative firm no longer has an incentive to precommit to share its information.

\section{Strategic Disclosure}

In the previous section firm $i$ was able to precommit to disclosure rules. In this section I characterize the innovative firm's incentives to disclose its production cost strategically. Subsequently, I study the effects of strategic disclosure on the firms' expected profits.

\subsection{Equilibrium Outputs}

I derive the outputs given any disclosure rule $(\delta(\underline{\theta}), \delta(\bar{\theta})) \in[0,1] \times[0,1]$, and any feasible, disclosed message, $D \in\{\underline{\theta}, \bar{\theta}, \varnothing\}$. After firm $i$ discloses information $\theta_{i}$ each firm supplies the full disclosure equilibrium output $x_{j}^{d}\left(\theta_{i} ; \kappa\right)$ for $j \in\{i, n\}$. If firm $i$ conceals its information $(D=\varnothing)$, then firm $j$ has beliefs consistent with the disclosure rule, and assigns probability $q$ to facing an efficient competitor, where:

$$
q \equiv \frac{p(1-\delta(\underline{\theta}))}{p(1-\delta(\underline{\theta}))+(1-p)(1-\delta(\bar{\theta}))} .
$$


Hence, firm $j$ 's posterior beliefs are such that his expectation of firm $i$ 's marginal cost is $E\left\{\theta_{i} \mid \varnothing\right\} \equiv q \underline{\theta}+(1-q) \bar{\theta}$.

The derivation of the equilibrium outputs under information concealment is similar to the derivation under full concealment, where $E\left\{x_{i}\left(\theta_{i}\right)\right\}$ is replaced by $E\left\{x_{i}\left(\theta_{i}\right) \mid \varnothing\right\}$. That is, if firm $i$ chooses a disclosure rule where $\delta(\underline{\theta}) \neq \delta(\bar{\theta})$, then information concealment is informative to firm $n$. Firm $n$ therefore updates its beliefs about its competitor's marginal cost after concealment, which yields expected cost $E\left\{\theta_{i} \mid \varnothing\right\}$. After an increase in $\delta(\underline{\theta})$ it is more likely that a concealing firm has a high marginal cost, and therefore posterior belief $q$ decreases, i.e. $\partial q / \partial \delta(\underline{\theta})<0$ and $\partial E\left\{\theta_{i} \mid \varnothing\right\} / \partial \delta(\underline{\theta})>0$. A decrease in the probability of disclosing a high marginal cost parameter, $\delta(\bar{\theta})$, has a similar effect. The firms' equilibrium output levels are (similar to expressions 3.6 and 3.7, respectively):

$$
\begin{aligned}
x_{i}^{s}\left(\theta_{i}\right) & =\frac{1}{3}\left(A-2 \theta_{i}+\bar{\theta}\right)+\frac{1}{6}\left(\theta_{i}-E\left\{\theta_{i} \mid \varnothing\right\}\right), \\
x_{n}^{s} & =\frac{1}{3}\left(A-2 \bar{\theta}+E\left\{\theta_{i} \mid \varnothing\right\}\right) .
\end{aligned}
$$

An increase of disclosure probability $\delta(\underline{\theta})$ increases the expected cost of firm $i$ after concealment, and consequently increases firm $n$ 's output $x_{n}^{s}$ while it lowers firm $i$ 's output $x_{i}^{s}\left(\theta_{i}\right)$.

\subsection{Equilibrium Disclosure}

In the previous subsection I characterized equilibrium outputs for any feasible disclosure rule. This subsection derives the disclosure rules which firm $i$ chooses in equilibrium.

First, I show that firm $i$ never has an incentive to disclose a high marginal cost $\bar{\theta}$, i.e. in equilibrium $\delta(\bar{\theta})=0$ for any spillover $\kappa$. After concealment firm $n$ expects firm $i$ to have a marginal cost lower or equal to $\bar{\theta}$, which makes firm $n$ less or equally "aggressive" as under disclosure of $\bar{\theta}$. Since outputs are strategic substitutes, firm $i$ therefore (weakly) prefers to conceal $\theta_{i}=\bar{\theta}$.

In the remainder of this subsection I study the equilibrium disclosure strategy of firm $i$ with a low marginal cost, given that firm $n$ anticipates disclosure rule 
$(\delta(\underline{\theta}), \delta(\bar{\theta}))=(\delta, 0)$, with $0 \leq \delta \leq 1$. Clearly, firm $i$ 's equilibrium disclosure strategy is determined by the comparison of the profit from disclosure and profit from concealment.

First, suppose that firm $n$ has beliefs consistent with disclosure of $\underline{\theta}$, i.e. $q=0$ and $E\left\{\theta_{i} \mid \varnothing\right\}=\bar{\theta}$. If firm $i$ conceals a low cost, then firm $n$ expects that firm $i$ is inefficient, and firm $n$ chooses output $x_{n}^{d}(\bar{\theta}, \kappa)$. Efficient firm $i$ 's best response to this output is to set output $x_{i}^{*} \equiv x_{i}\left(x_{n}^{d}(\bar{\theta}, \kappa) ; \underline{\theta}\right)$, as illustrated in Figure 6 below. The firms'

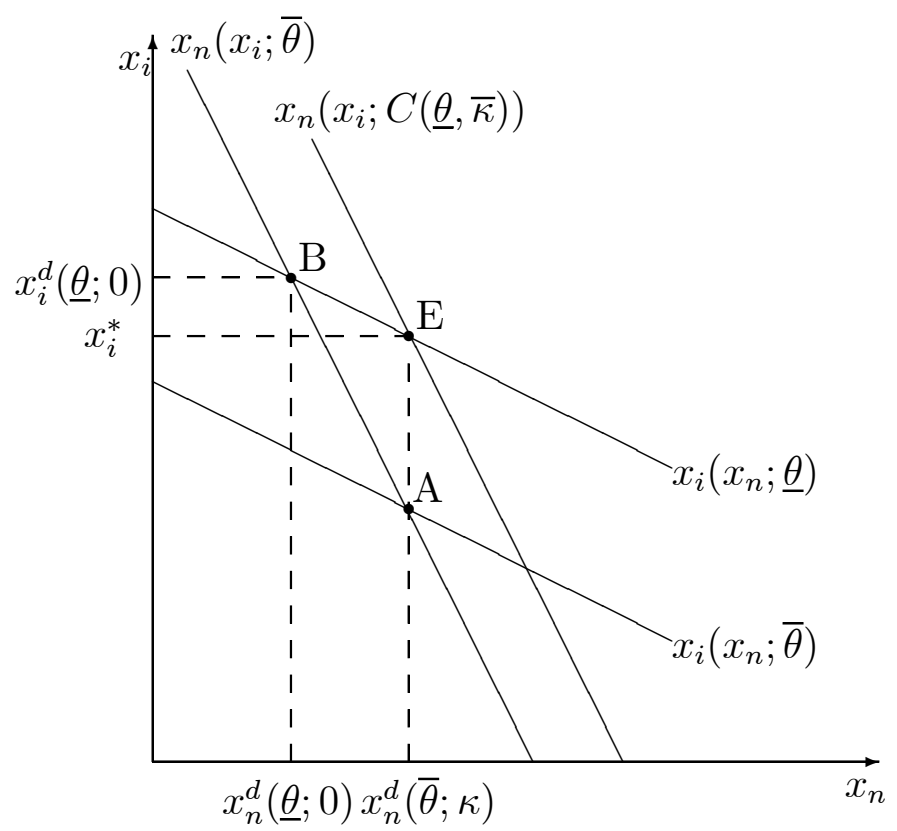

Figure 6: Incentive to Disclose

outputs are such that point $\mathrm{E}$ in the figure is reached. If firm $i$ discloses a low cost with probability one, then both firms supply their full disclosure outputs. Now, as illustrated in Figure 6 , a critical spillover, $\bar{\kappa} \in(0,1)$, exists such that for this spillover firm $n$ 's best response curve after disclosure of $\underline{\theta}$, i.e. $x_{n}\left(x_{i} ; C(\underline{\theta}, \bar{\kappa})\right)$, runs through point E. For any spillover smaller or equal to $\bar{\kappa}$ the equilibrium after disclosure of $\underline{\theta}$ is on the line B-E, and disclosure yields an equilibrium output for firm $i$ greater or equal than $x_{i}^{*}$. Since firm $i$ 's equilibrium profit is increasing in its equilibrium output level, disclosure of $\underline{\theta}$ is more or equally profitable than concealment for any knowledge spillover below or equal to $\bar{\kappa}$. For these spillover values disclosure of a low cost is an equilibrium strategy. That is, for $\kappa<\bar{\kappa}$ the strategic effect of disclosure outweighs 
the technology expropriation effect, given beliefs consistent with full disclosure.

Second, suppose that firm $n$ has beliefs consistent with full concealment, i.e. $q=p$ and $E\left\{\theta_{i} \mid \varnothing\right\}=E\left\{\theta_{i}\right\}$. Now, if firm $i$ conceals a low cost, both firms supply their full concealment output levels. That is, point $\mathrm{D}$ in Figure 7 below is reached. On the

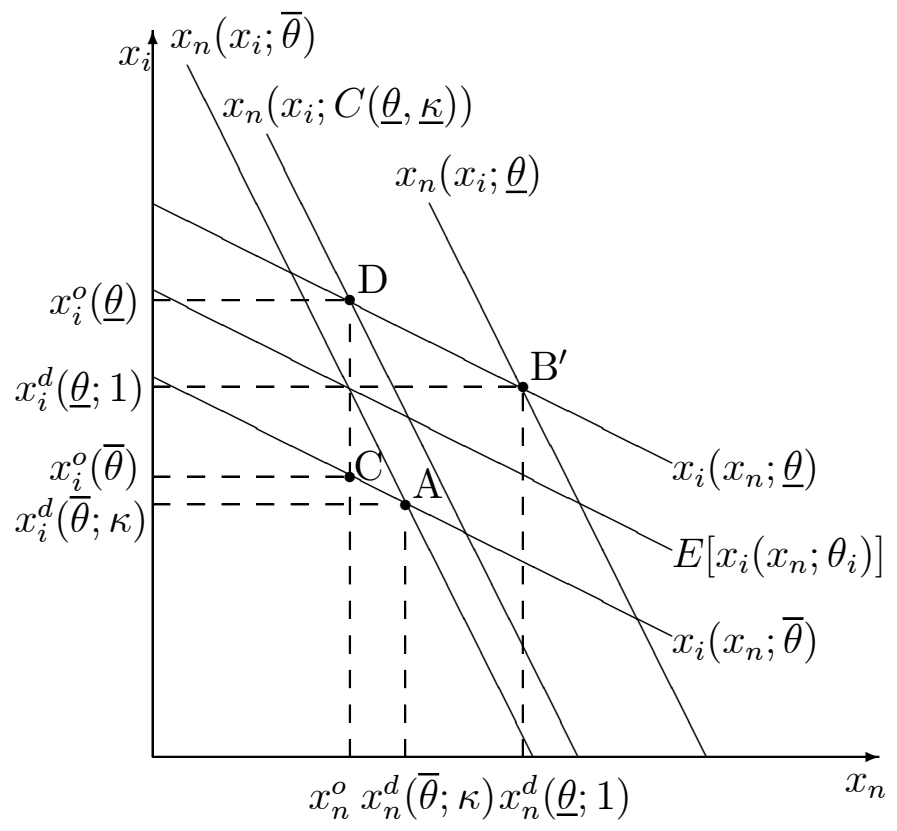

Figure 7: Incentive to Conceal

other hand, point $\mathrm{D}$ will be reached after disclosure of a low cost, if the knowledge spillover is such that firm $n$ 's best response curve after disclosure, $x_{n}\left(x_{i} ; C(\underline{\theta}, \kappa)\right)$, runs through point $\mathrm{D}$. We define $\underline{\kappa}$ as the critical spillover value for which this happens, where $0<\underline{\kappa}<1$. For all spillovers greater of equal than $\underline{\kappa}$ the equilibrium outputs after disclosure are on the line D-B'. These equilibrium output levels are below or equal to $x_{i}^{o}(\underline{\theta})$ for firm $i$, and yield therefore profits below or equal to the profit from concealment. In other words, for all spillovers greater of equal than $\underline{\kappa}$, concealment is an equilibrium strategy for firm $i$.

Finally, it is clear from comparing Figures 6 and 7 that critical spillovers $\underline{\kappa}$ and $\bar{\kappa}$ are such that $\underline{\kappa}<\bar{\kappa}$, since point $\mathrm{D}$ is clearly to the left of $\mathrm{E}$, as is illustrated in Figure 8 below. If $\underline{\kappa}<\kappa<\bar{\kappa}$, firm $i$ may choose a partial disclosure rule in equilibrium, i.e. $(\delta(\underline{\theta}), \delta(\bar{\theta}))=\left(\delta^{*}, 0\right)$ with $0<\delta^{*}<1$. If firm $n$ has beliefs consistent with partial disclosure, i.e. $0<q<p$ and $E\left\{\theta_{i}\right\}<E\left\{\theta_{i} \mid \varnothing\right\}<\bar{\theta}$, and firm $i$ 


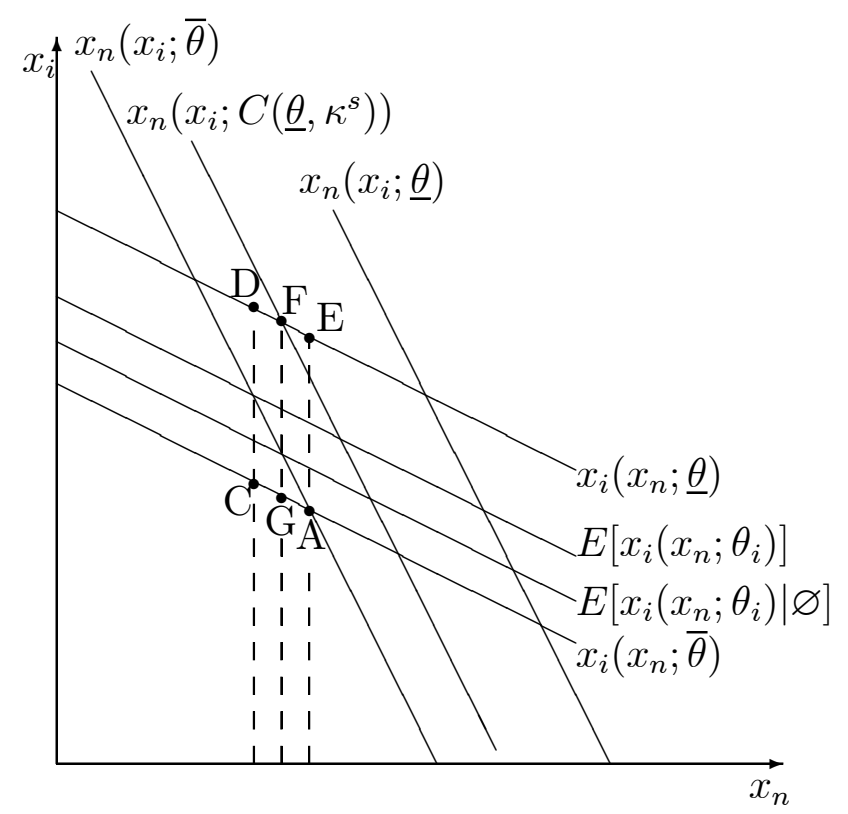

Figure 8: Incentive for Partial Disclosure

conceals its cost, then firm $n$ chooses output level $x_{n}^{s}$. Output $x_{n}^{s}$ is the output level where firm $n$ 's best response curve $x_{n}\left(x_{i} ; \bar{\theta}\right)$ crosses firm $i$ 's expected best response curve, given beliefs consistent with disclosure rule $\left(\delta^{*}, 0\right)$, i.e. $E\left[x_{i}\left(x_{n} ; \theta_{i}\right) \mid \varnothing\right]$. This output lies between the output levels under full concealment and full disclosure, i.e. $x_{n}^{o}$ and $x_{n}^{d}(\bar{\theta}, \kappa)$ respectively, since expected best response curve $E\left[x_{i}\left(x_{n} ; \theta_{i}\right) \mid \varnothing\right]$ lies between the expected best response curve given prior beliefs, $E\left[x_{i}\left(x_{n} ; \theta_{i}\right)\right]$, and the best response curve of inefficient firm $i, x_{i}\left(x_{n} ; \bar{\theta}\right)$. Efficient firm $i$ 's best response to $x_{n}^{s}$ is to supply $x_{i}^{s}(\underline{\theta})$. This equilibrium is illustrated by point $\mathrm{F}$ in Figure 8 . Notice that point $\mathrm{F}$ lies between points $\mathrm{D}$ and $\mathrm{E}$. Clearly, there exists one spillover value $\kappa^{s}$ between $\underline{\kappa}$ and $\bar{\kappa}$ such that firm $n$ 's best response curve runs through point $\mathrm{F}$, and firm $i$ is indifferent between disclosure and concealment. Such a posterior belief and spillover value support the partial disclosure rule $(\delta(\underline{\theta}), \delta(\bar{\theta}))=\left(\delta^{*}, 0\right)$ as an equilibrium strategy.

An increase of $\delta^{*}$ implies that firm $n$ expects a less efficient competitor after concealment, i.e. firm $i$ 's expected best response curve $E\left[x_{i}\left(x_{n} ; \theta_{i}\right) \mid \varnothing\right]$ shifts downwards. Firm $n$ 's equilibrium output does therefore increase, and efficient firm $i$ 's output decreases. In other words, the equilibrium shifts to the right along line D-E in Figure 
8. Only an equal shift to the right of firm $n$ 's best response curve can maintain firm $i$ 's indifference between disclosure and concealment of $\underline{\theta}$. Hence, knowledge spillover $\kappa^{s}$ needs to increase after $\delta^{*}$ increases. In summary, the equilibrium partial disclosure probability $\delta^{*}$ is increasing in the spillover $\kappa$.

Analytically, the critical values $\underline{\kappa}$ and $\bar{\kappa}$ are defined as:

$$
\underline{\kappa} \equiv \frac{1}{2}(1-p) \text { and } \bar{\kappa} \equiv \frac{1}{2}
$$

respectively, and the equilibrium partial disclosure probability is as follows:

$$
\delta^{*}(\kappa) \equiv 1-\frac{(1-p)(1-2 \kappa)}{2 p \kappa} .
$$

This completes the characterization of the strategic disclosure incentives, and yields the following proposition.

Proposition 2 The critical spillover values $\underline{\kappa}$ and $\bar{\kappa}$ exist, as defined in (4.4) i.e. $0<\underline{\kappa}<\bar{\kappa}<1$, such that firm $i$ chooses the following disclosure rules in equilibrium: (a) if $\kappa<\underline{\kappa}$, firm i's equilibrium disclosure rule is unique, and yields full disclosure;

(b) if $\underline{\kappa} \leq \kappa \leq \bar{\kappa}$, three equilibrium disclosure rules exist, yielding either full disclosure, full concealment, or partial disclosure $(\delta(\underline{\theta}), \delta(\bar{\theta}))=\left(\delta^{*}(\kappa), 0\right)$ with $\delta^{*}(\kappa)$ as in (4.5), i.e. $d \delta^{*} / d \kappa>0, \delta^{*}(\underline{\kappa})=0$, and $\delta^{*}(\bar{\kappa})=1$;

(c) if $\kappa>\bar{\kappa}$, firm i's equilibrium disclosure rule is unique, and yields full concealment.

This result illustrates that the unraveling result in Okuno-Fujiwara et al. (1990) is robust to the introduction of small knowledge spillovers. For sufficiently high knowledge spillovers (in particular, for $\kappa>\bar{\kappa}$ ), however, the non-monotonicity of best response functions creates sufficiently strong incentives to conceal information, and consequently the unraveling result fails.

\subsection{Profit Comparison}

In this subsection I compare expected profits under the equilibrium disclosure rules. The expected profits under full disclosure and no disclosure are already given in expressions (3.8) and (3.9), respectively. If the spillover is $\kappa^{s}$ from Figure 8, the expected 
profit of firm $i$ under partial disclosure $(\delta(\underline{\theta}), \delta(\bar{\theta}))=\left(\delta^{*}, 0\right)$ equals:

$$
\begin{aligned}
\Pi_{i}^{s}\left(\kappa^{s}\right) & =p \delta^{*} x_{i}^{d}\left(\underline{\theta} ; \kappa^{s}\right)^{2}+p\left(1-\delta^{*}\right) x_{i}^{s}(\underline{\theta})^{2}+(1-p) x_{i}^{s}(\bar{\theta})^{2} \\
& =p x_{i}^{d}\left(\underline{\theta} ; \kappa^{s}\right)^{2}+(1-p) x_{i}^{s}(\bar{\theta})^{2}
\end{aligned}
$$

since, by construction, $x_{i}^{d}\left(\underline{\theta} ; \kappa^{s}\right)=x_{i}^{s}(\underline{\theta})$ for equilibrium disclosure rule $\left(\delta^{*}, 0\right)$.

The comparison of firm $i$ 's expected profit under full and partial disclosure reduces to the comparison between $x_{i}^{d}\left(\bar{\theta} ; \kappa^{s}\right)$ and $x_{i}^{s}(\bar{\theta})$. In Figure 8 this comparison is between points A and G, respectively. Clearly, point A yields a lower output for firm $i$ than point $\mathrm{G}$, i.e. $x_{i}^{d}\left(\bar{\theta} ; \kappa^{s}\right)<x_{i}^{s}(\bar{\theta})$, and consequently $\Pi_{i}^{d}\left(\kappa^{s}\right)<\Pi_{i}^{s}\left(\kappa^{s}\right)$. The comparison of firm $i$ 's expected profit under partial disclosure and full concealment is illustrated by the comparison between points $\mathrm{F}$ and $\mathrm{D}$, and points $\mathrm{G}$ and $\mathrm{C}$ in Figure 8. Both comparisons yield the highest output levels for firm $i$ under full concealment, i.e. (D,C). Hence, firm $i$ earns the greatest expected profit under full concealment, i.e. $\Pi_{i}^{s}\left(\kappa^{s}\right)<\Pi_{i}^{o}$. Clearly, a similar comparison emerges for any other spillover between $\underline{\kappa}$ and $\bar{\kappa}$. Therefore, firm $i$ 's expected equilibrium profits are such that: $\Pi_{i}^{d}(\kappa)<$ $\Pi_{i}^{s}(\kappa)<\Pi_{i}^{o}$ for all $\underline{\kappa}<\kappa<\bar{\kappa}$.

Finally, the expected profit of firm $n$ given partial disclosure by firm $i$ and spillover $\kappa^{s}$ from Figure 8 equals:

$$
\Pi_{n}^{s}\left(\kappa^{s}\right)=p \delta^{*} x_{n}^{d}\left(\underline{\theta} ; \kappa^{s}\right)^{2}+\left[p\left(1-\delta^{*}\right)+1-p\right]\left(x_{n}^{s}\right)^{2}=x_{n}^{d}\left(\underline{\theta} ; \kappa^{s}\right)^{2}
$$

since $x_{n}^{d}\left(\underline{\theta} ; \kappa^{s}\right)=x_{n}^{s}$, as illustrated in Figure 8 (point F). The comparison of expected profits under full disclosure and partial disclosure is essentially a comparison between $x_{n}^{d}\left(\bar{\theta} ; \kappa^{s}\right)$ and $x_{n}^{d}\left(\underline{\theta} ; \kappa^{s}\right)$, or points A and $\mathrm{G}$, respectively. Under full disclosure firm $n$ has a higher expected profit (i.e. point $\mathrm{A}$ is to the right of $\mathrm{G}$ in Figure 8). Firm $n$ 's output level under full concealment is below its output level under partial disclosure (e.g. point $\mathrm{C}$ is to the left of point $\mathrm{G}$ in Figure 8), and therefore firm $n$ earns the lowest expected profit under full concealment. Hence, I have illustrated that: $\Pi_{n}^{o}<\Pi_{n}^{s}(\kappa)<\Pi_{n}^{d}(\kappa)$ for all $\underline{\kappa}<\kappa<\bar{\kappa}$. I state this formally in the following proposition. 
Proposition 3 For knowledge spillover $\kappa \in(\underline{\kappa}, \bar{\kappa})$, with $\underline{\kappa}$ and $\bar{\kappa}$ as in (4.4), the firms' expected equilibrium profits under partial disclosure $(\delta(\underline{\theta}), \delta(\bar{\theta}))=\left(\delta^{*}, 0\right)$, with $\delta^{*}$ as in (4.5), are between the expected profits under precommitment, i.e. $\Pi_{i}^{d}(\kappa)<\Pi_{i}^{s}(\kappa)<\Pi_{i}^{o}$ and $\Pi_{n}^{o}<\Pi_{n}^{s}(\kappa)<\Pi_{n}^{d}(\kappa)$.

An immediate implication of the analysis of firm $i$ 's expected profits above, and monotonicity and continuity of the expected profit functions, is that the critical value $\kappa^{*}$ from Proposition 1 is below $\underline{\kappa}$. This result is illustrated in Figure 7. For spillover $\kappa=\underline{\kappa}$ firm $i$ 's ex ante expected profit from concealment is greater than the expected profit from disclosure. By construction, an efficient firm $i$ is indifferent between disclosure and concealment. But an inefficient firm $i$ makes a greater profit after concealment, since its output after concealment is greatest (i.e. $x_{i}^{o}(\bar{\theta})>x_{i}^{d}(\bar{\theta} ; \kappa)$ as illustrated in e.g. Figure 7$)$. Since $\Pi_{i}^{d}(\kappa)$ is decreasing in $\kappa$, and $\Pi_{i}^{o}>\Pi_{i}^{d}(\underline{\kappa})$, critical value $\kappa^{*}$ must be below $\underline{\kappa}$, as is stated below.

Corollary 1 Critical values $\kappa^{*}, \underline{\kappa}$ and $\bar{\kappa}$, from propositions 1 and 2 are such that: $\kappa^{*}<\underline{\kappa}<\bar{\kappa}$.

Intuitively, this result is due to the fact that under strategic disclosure an efficient firm ignores the negative externality that its disclosure choice inflicts on its inefficient counterpart. Under precommitment the innovative firm internalizes this externality, which reduces the firm's incentive to disclose a low cost.

An implication of Propositions 1 and 2, and the corollary is that if firm $i$ precommits, it conceals its information for more knowledge spillover values than if it discloses strategically. In particular, for spillovers $\kappa^{*}<\kappa<\underline{\kappa}$ the firm prefers to precommit to full concealment (see Proposition 1), while it strategically discloses its information in the unique disclosure equilibrium (see Proposition 2). In the next section I discuss some economic policy implications of this observation. 


\section{Antitrust Analysis}

Should an antitrust authority prohibit an innovative firm to precommit to disclose its process innovation, or should precommitment be encouraged? I address this question here.

First, I discuss the effects of information disclosure on the expected consumers' surplus. If the innovative firm's technology cannot be expropriated, i.e. $\kappa=0$, then the consumers' surplus is greatest under full disclosure. For example, Shapiro (1986) shows this formally, and Kühn and Vives (1995) give a graphical illustration. An increase of the knowledge spillover reduces the expected equilibrium price under full disclosure, since imitation reduces the expected cost of firm $n$. The expected price reduction increases the expected consumers' surplus under full disclosure, i.e. the expected consumers' surplus under full disclosure is increasing in spillover $\kappa$. Clearly, the consumers' surplus under full concealment does not depend on the spillover. If the spillover equals $\underline{\kappa}$ as in (4.4), then the consumers' surplus under full disclosure is greater than the consumers' surplus under full concealment. Consequently, due to continuity and monotonicity of the consumers' surplus, there exists a critical value $\kappa^{c}$ with $0<\kappa^{c}<\underline{\kappa}$ such that for all spillovers greater than $\kappa^{c}$ the consumers' surplus is highest under full disclosure. Hence, if the antitrust authority maximizes exclusively the consumers' surplus, she should prohibit precommitment for all $\kappa \geq \kappa^{c}$. In particular, if $\kappa^{c} \leq \kappa^{*}$, then precommitment should always be prohibited.

Second, if an antitrust authority maximizes social welfare, i.e. the sum of the consumers' surplus and the industry profits, then the following trade-offs emerge for extreme spillover values. If $\kappa=0$, expected industry profits are greatest but expected consumers' surplus is smallest under full disclosure. As e.g. Shapiro (1986) shows, expected welfare is highest under full disclosure, i.e. the profit effect outweighs the consumers' surplus effect. Conversely, if $\kappa=1$, then full disclosure yields a higher expected consumers' surplus and expected profit of firm $n$, but a lower expected profit for firm $i$. Although the trade-off differs from the one I had before, expected welfare remains greatest under full disclosure. For intermediate knowledge spillovers an in- 
crease of spillover $\kappa$ creates the following trade-off for antitrust authority under full disclosure. On the one hand, firm $i$ 's expected profit decreases, but, on the other hand, both the expected consumers' surplus and firm n's expected profit increase. Finally, it is easy to show that if demand is sufficiently strong (i.e. the intercept $A$ is sufficiently great), then the expected welfare is increasing in $\kappa$. Consequently, if demand is sufficiently strong, then expected welfare is greatest under full disclosure, and a welfare-maximizing antitrust authority should prohibit precommitment to communication between firms.

I state and prove these results formally in the following proposition.

Proposition 4 (a) The critical value $\kappa^{c}$ exists, with $0<\kappa^{c}<\underline{\kappa}$, and $\underline{\kappa}$ as in (4.4), such that for all $\kappa \geq \kappa^{c}$ the expected consumers' surplus is highest under prohibition of precommitment. (b) If $A>\frac{1}{4}(11 \bar{\theta}-7 \underline{\theta})$, then expected social welfare is highest under prohibition of precommitment.

The previous discussion suggests that an antitrust authority should prohibit the firms to precommit to information sharing rules in many relevant cases. The prohibition of precommitment may have an additional advantage, since it may also help the antitrust authority to fight collusion.

\section{Conclusion}

In this paper I analyzed the effects of disclosure regulation and knowledge spillovers on disclosure incentives and product market competition. The analysis was conducted for industries where firms are Cournot competitors, and where the innovative firm makes announcements about a process innovation.

I have shown that disclosure regulation substantially affects firms' outputs and profits for intermediate values of the knowledge spillover. For these knowledge spillover values a strategic innovative firm discloses its technology in more cases than a precommitted firm. The precommitted firm has a lower incentive to disclose its technology since the firm internalizes a negative externality that the disclosure of an efficient 
technology inflicts on the profit of the firm with an inefficient technology. An antitrust authority can use disclosure regulation to exploit the effect of this externality on the firms' product market conduct. Prohibiting the innovative firm to precommit to information sharing rules yields more (strategic) technology disclosure, and thereby potentially a higher consumers' surplus and social welfare.

For extreme spillover values, i.e. when only very little or most of the disclosed technology can be expropriated, disclosure regulation does not affect the firms' conduct. In both cases, however, the prohibition of precommitment can have the additional advantage of helping to fight collusion between firms.

\section{A Appendix}

This Appendix contains proofs of propositions 2, 3, and 4.

\section{A.1 Proof of Proposition 2}

Define critical spillover values $\underline{\kappa}$ and $\bar{\kappa}$ as in (4.4). Firm $i$ 's profit from disclosure equals:

$$
\begin{aligned}
\pi_{i}^{s}(\underline{\theta} \mid \underline{\theta}) & =x_{i}^{d}(\underline{\theta} ; \kappa)^{2}=\frac{1}{9}(A-2 \underline{\theta}+C(\underline{\theta}, \kappa))^{2} \\
& =\frac{1}{9}[(A-2 \underline{\theta}+\bar{\theta})-\kappa(\bar{\theta}-\underline{\theta})]^{2} .
\end{aligned}
$$

The firm's profit from concealment is:

$$
\begin{aligned}
\pi_{i}^{s}(\varnothing \mid \underline{\theta}) & =x_{i}^{s}(\underline{\theta} ; \varnothing)^{2}=\frac{1}{9}\left(A-2 \underline{\theta}+\bar{\theta}+\frac{1}{2}\left(\underline{\theta}-E\left\{\theta_{i} \mid \varnothing\right\}\right)\right)^{2} \\
& =\frac{1}{9}\left((A-2 \underline{\theta}+\bar{\theta})-\frac{1}{2}(1-q)(\bar{\theta}-\underline{\theta})\right)^{2} .
\end{aligned}
$$

The comparison of profits $\pi_{i}^{s}(\underline{\theta} \mid \underline{\theta})$ and $\pi_{i}^{s}(\varnothing \mid \underline{\theta})$ yields the following immediate observations.

Full disclosure, $(\delta(\underline{\theta}), \delta(\bar{\theta}))=(1,0)$, is optimal if $\pi_{i}^{s}(\underline{\theta} \mid \underline{\theta})>\pi_{i}^{s}(\varnothing \mid \underline{\theta})$ or $\kappa<\frac{1}{2}(1-q)$. Firm $n$ 's posterior belief is consistent with full disclosure if $q=0$. Hence, full disclosure is an equilibrium strategy for all $\kappa<\bar{\kappa}$. On the other hand, full concealment, $(\delta(\underline{\theta}), \delta(\bar{\theta}))=(0,0)$, is optimal if $\pi_{i}^{s}(\underline{\theta} \mid \underline{\theta})<\pi_{i}^{s}(\varnothing \mid \underline{\theta})$ or $\kappa>\frac{1}{2}(1-q)$. The posterior belief consistent with full concealment is $q=p$. Therefore, full concealment is an 
equilibrium disclosure rule for all $\kappa>\underline{\kappa}$. Finally, a partial disclosure rule exists in equilibrium, i.e. $(\delta(\underline{\theta}), \delta(\bar{\theta}))=\left(\delta^{*}, 0\right)$ with $0<\delta^{*}<1$, if firm $i$ is indifferent between disclosure and concealment, given posterior beliefs consistent with partial disclosure. Indifference emerges if $\kappa=\frac{1}{2}(1-q)$. Using definition (4.1), it is straightforward to obtain the following expression:

$$
\kappa=\frac{1}{2} \cdot \frac{1-p}{p\left(1-\delta^{*}\right)+1-p}
$$

which yields equilibrium probability $\delta^{*}(\kappa)$ in (4.5). Clearly, this partial disclosure equilibrium exists for spillovers such that $\underline{\kappa}<\kappa<\bar{\kappa}$, and the partial disclosure probability $\delta^{*}$ is increasing in $\kappa$. This completes the proof.

\section{A.2 Proof of Proposition 3}

Firm $i$ 's expected profit under partial disclosure is decreasing in the knowledge spillover, since all terms of the following expression are negative:

$$
\begin{aligned}
\frac{d \Pi_{i}^{s}(\kappa)}{d \kappa}= & p \delta^{*} \frac{\partial \pi_{i}^{d}(\underline{\theta} ; \kappa)}{\partial \kappa} \\
& +\left[p\left(1-\delta^{*}\right)+1-p\right]\left(q \frac{\partial \pi_{i}^{s}(\underline{\theta} ; \varnothing)}{\partial \delta(\underline{\theta})}+(1-q) \frac{\partial \pi_{i}^{s}(\bar{\theta} ; \varnothing)}{\partial \delta(\underline{\theta})}\right) \frac{d \delta^{*}}{d \kappa} .
\end{aligned}
$$

Furthermore, if $\kappa=\underline{\kappa}$, as defined in proposition 2 , then $\delta^{*}=0$, and $\Pi_{i}^{o}=\Pi_{i}^{s}(\underline{\kappa})$. Since $\Pi_{i}^{o}$ is constant while $\Pi_{i}^{s}(\kappa)$ is decreasing in $\kappa$, it follows immediately that $\Pi_{i}^{o}>\Pi_{i}^{s}(\kappa)$ for all $\underline{\kappa}<\kappa \leq \bar{\kappa}$, with $\underline{\kappa}$ and $\bar{\kappa}$ as defined in proposition 2 . The comparison of the expected profits under full and partial disclosure gives the following. If $\kappa=\bar{\kappa}$, then $\delta^{*}=1$ and $\Pi_{i}^{s}(\bar{\kappa})>\Pi_{i}^{d}(\bar{\kappa})$. For lower spillover values the comparison between firm $i$ 's expected profit under full disclosure (3.8) with $j=i$, and the expected profit under partial disclosure (4.6) reduces to the comparison of $x_{i}^{d}(\bar{\theta} ; \kappa)$ and $x_{i}^{s}(\bar{\theta})$, respectively. Since expressions (3.3) and (4.2) yield

$$
x_{i}^{s}(\bar{\theta})=\frac{1}{3}\left(A-2 \bar{\theta}+\bar{\theta}+\frac{1}{2}\left(\bar{\theta}-E\left\{\theta_{i} \mid \varnothing\right\}\right)>\frac{1}{3}(A-2 \bar{\theta}+\bar{\theta})=x_{i}^{d}(\bar{\theta} ; \kappa),\right.
$$

I obtain $\Pi_{i}^{s}(\kappa)>\Pi_{i}^{d}(\kappa)$ for all $\underline{\kappa} \leq \kappa<\bar{\kappa}$. Hence, the innovative firm's expected profits under partial disclosure is between its expected profits under the two precommitment regimes, i.e. $\Pi_{i}^{d}(\kappa)<\Pi_{i}^{s}(\kappa)<\Pi_{i}^{o}$ for all $\underline{\kappa}<\kappa<\bar{\kappa}$.

Finally, firm $n$ 's expected profit under partial disclosure $(\delta(\underline{\theta}), \delta(\bar{\theta}))=\left(\delta^{*}, 0\right)$ is increasing in the spillover, since:

$$
\frac{d \Pi_{n}^{s}(\kappa)}{d \kappa}=p \delta^{*} \frac{\partial \pi_{n}^{d}(\underline{\theta} ; \kappa)}{\partial \kappa}+\left[p\left(1-\delta^{*}\right)+1-p\right] \frac{\partial \pi_{n}^{s}(\varnothing)}{\partial \delta(\underline{\theta})} \cdot \frac{d \delta^{*}}{d \kappa}>0
$$


Moreover, if $\kappa=\underline{\kappa}$, then $\delta^{*}=0$, and $\Pi_{n}^{o}=\Pi_{n}^{s}(\underline{\kappa})$. Since $\Pi_{n}^{o}$ is constant while $\Pi_{n}^{s}(\kappa)$ is increasing in $\kappa$, it follows immediately that $\Pi_{n}^{o}(\kappa)<\Pi_{n}^{s}(\kappa)$ for all $\underline{\kappa}<\kappa \leq \bar{\kappa}$. On the other hand, if $\kappa=\bar{\kappa}$, then $\delta^{*}=1$ and $\Pi_{n}^{s}(\bar{\kappa})=\Pi_{n}^{d}(\bar{\kappa})$. For $\kappa<\bar{\kappa}$ the comparison between firm $n$ 's expected profit under full disclosure (3.8) with $j=n$, and partial disclosure (4.7) is essentially a comparison between outputs $x_{n}^{d}(\bar{\theta} ; \kappa)$ and $x_{n}^{d}(\underline{\theta} ; \kappa)$, respectively. Clearly, the comparison of (3.4) for $\theta_{i}=\bar{\theta}$ and $\theta_{i}=\underline{\theta}$ yields:

$$
x_{n}^{d}(\bar{\theta} ; \kappa)-x_{n}^{d}(\underline{\theta} ; \kappa)=\frac{1}{3}(1-2 \kappa)(\bar{\theta}-\underline{\theta})>0
$$

for all $\kappa<\bar{\kappa}$. Hence, $\Pi_{n}^{s}(\kappa)<\Pi_{n}^{d}(\kappa)$ for all $\underline{\kappa} \leq \kappa<\bar{\kappa}$. Combining the two profit comparisons gives: $\Pi_{n}^{o}<\Pi_{n}^{s}(\kappa)<\Pi_{n}^{d}(\kappa)$ for all $\underline{\kappa}<\kappa<\bar{\kappa}$. This completes the proof.

\section{A.3 Proof of Proposition 4}

For a given industry output $X$ the consumers' surplus equals $\frac{1}{2} X^{2}$. Social welfare is the sum of the consumers' surplus and the total profits, i.e. $W \equiv \frac{1}{2} X^{2}+\pi_{i}+\pi_{n}$. From (3.3) and (3.4) I derive the industry output under full disclosure:

$$
X^{d}\left(\theta_{i} ; \kappa\right)=\frac{1}{3}\left(2 A-\theta_{i}-C\left(\theta_{i}, \kappa\right)\right)
$$

Adding up (3.6) and (3.7) gives the industry output under full concealment:

$$
X^{o}\left(\theta_{i}\right)=\frac{1}{3}\left(2 A-\theta_{i}-\bar{\theta}+\frac{1}{2}\left(E\left\{\theta_{i}\right\}-\theta_{i}\right)\right) .
$$

(a) First, notice that the consumers' surplus under full disclosure is increasing in spillover $\kappa: \partial E\left\{\frac{1}{2} X^{d}\left(\theta_{i} ; \kappa\right)^{2}\right\} / \partial \kappa=p X^{d}(\underline{\theta} ; \kappa) \cdot \partial X^{d}(\underline{\theta} ; \kappa) / \partial \kappa>0$, since $\partial X^{d}(\underline{\theta} ; \kappa) / \partial \kappa>$ 0 as follows from (A.8). For $\kappa=\underline{\kappa}\left(=\frac{1}{2}(1-p)\right)$, the following holds:

$$
\begin{aligned}
X^{d}(\underline{\theta} ; \underline{\kappa}) & =\frac{1}{3}(2 A-\underline{\theta}-\bar{\theta}+\underline{\kappa}(\bar{\theta}-\underline{\theta})) \\
& =\frac{1}{3}\left(2 A-\underline{\theta}-\bar{\theta}+\frac{1}{2}(1-p)(\bar{\theta}-\underline{\theta})\right)=X^{o}(\underline{\theta})
\end{aligned}
$$

while $X^{d}(\bar{\theta} ; \underline{\kappa})>X^{o}(\bar{\theta})$. Hence, $E\left\{X^{d}\left(\theta_{i} ; \underline{\kappa}\right)^{2}\right\}>E\left\{X^{o}\left(\theta_{i}\right)^{2}\right\}$. Continuity and monotonicity of the consumers' surplus immediately yield the existence of a critical value $\kappa^{c}$ with $0<\kappa^{c}<\underline{\kappa}$ such that for all $\kappa \geq \kappa^{c}$ the consumers' surplus is highest under full disclosure. 
(b) As shown in e.g. Shapiro (1986) $E\left\{W^{d}\left(\theta_{i} ; \kappa\right)\right\}>E\left\{W^{o}\left(\theta_{i}\right)\right\}$ for $\kappa=0$. The expected welfare under full disclosure depends as follows on the spillover $\kappa$ :

$$
\begin{aligned}
\frac{\partial E\left\{W^{d}\left(\theta_{i} ; \kappa\right)\right\}}{\partial \kappa} & =p X^{d}(\underline{\theta} ; \kappa) \frac{\partial X^{d}(\underline{\theta} ; \kappa)}{\partial \kappa}+2 p \sum_{j \in\{i, n\}} x_{j}^{d}(\underline{\theta} ; \kappa) \frac{\partial x_{j}^{d}(\underline{\theta} ; \kappa)}{\partial \kappa} \\
& =\frac{p}{9}(\bar{\theta}-\underline{\theta})[(2 A-\underline{\theta}-C(\underline{\theta}, \kappa))+2(A+4 \underline{\theta}-5 C(\underline{\theta}, \kappa))] \\
& =\frac{p}{9}(\bar{\theta}-\underline{\theta})[4 A+7 \underline{\theta}-11 C(\underline{\theta}, \kappa)]
\end{aligned}
$$

which is positive for all $\kappa$ if $A>\frac{1}{4}(11 \bar{\theta}-7 \underline{\theta})$. Consequently, if $A>\frac{1}{4}(11 \bar{\theta}-7 \underline{\theta})$, $E\left\{W^{d}\left(\theta_{i} ; \kappa\right)\right\}>E\left\{W^{o}\left(\theta_{i}\right)\right\}$ for all $\kappa$. This completes the proof.

\section{References}

Anton, J.J. And YaO, D.A. "Patents, Invalidity, and the Strategic Transmission of Enabling Information", Journal of Economics and Management Strategy Vol. 12 (2003), pp. 151-178

Anton, J.J. And Yao, D.A. "Little Patents and Big Secrets: Managing Intellectual Property", RAND Journal of Economics Vol. 35 (2004), pp. 1-22

D'Aspremont, C. And Jacquemin, A. "Cooperative and Noncooperative R\&D in Duopoly with Spillovers", American Economic Review Vol. 78 (1988), pp. 1133-1142

Bayus, B.L., Jain, S. And RaO, A.G. "Truth or Consequences: An Analysis of Vaporware and New Product Announcements", Journal of Marketing Research Vol. 38 (2001), pp. 3-13

Choi, J.P., Kristiansen, E.G. And Nahm, J. "Vaporware", mimeo, 2004

Dranove, D. and Gandal, N. "The DVD-vs.-DIVX Standard War: Empirical Evidence of Network Effects and Preannouncement Effects", Journal of Economics and Management Strategy Vol. 12 (2003), pp. 363-386

Dye, R.A. "An Evaluation of 'Essays on Disclosure' and the Disclosure Literature in Accounting", Journal of Accounting and Economics Vol. 32 (2001), pp. 181-235

Farrell, J. And Saloner, G. "Installed Base and Compatibility: innovation, prod- 
uct preannouncements, and predation", American Economic Review Vol. 76 (1986), pp. $940-955$

FRIED, D. "Incentives for Information Production and Disclosure in a Duopolistic Environment", Quarterly Journal of Economics Vol. 99 (1984), pp. 367-381

GAL-OR, E. "Information Transmission - Cournot and Bertrand Equilibria", Review of Economic Studies Vol. 53 (1986), pp. 85-92

Gerlach, H.A. "Announcement, Entry, and Preemption When Consumers Have Switching Costs", RAND Journal of Economics Vol. 35 (2004), pp. 184-202

Gertner, R.H. "Disclosure and Unraveling", in Peter, N. (Ed.) The New Palgrave Dictionary of Economics and the Law, MacMillan Press, London, 1998

GILL, D. "Strategic Disclosure of Intermediate Research Results", mimeo, 2004, University of Oxford, Department of Economics Discussion Paper Series nr. 211

Grossman, S.J. "The Informational Role of Warranties and Private Disclosure about Product Quality", Journal of Law and Economics Vol. 24 (1981), pp. 461-483

HAAn, M.A. "Vaporware as a Means of Entry Deterrence" Journal of Industrial Economics Vol. 51 (2003), pp. 345-358

JAnsen, J. "Strategic Information Revelation in an R\&D Race with Spillovers", mimeo, 2004

Jansen, J. "Technology Sharing Incentives with Weak Intellectual Property Rights", mimeo, 2005

Jin, J.Y. "Innovation Announcement with Vertical Differentiation" Journal of Economic Behavior and Organization Vol. 28 (1995), pp. 399-408

Kamien, M.I., Muller, E. And Zang, I. "Research Joint Ventures and R\&D Cartels", American Economic Review Vol. 82 (1992), pp. 1293-1306

Katsoulacos, Y. And Ulph, D. "Endogenous Spillovers and the Performance of 
Research Joint Ventures", Journal of Industrial Economics Vol. 46 (1998), pp. 333357

KÜHn, K-U. "Fighting Collusion by Regulating Communication between Firms", Economic Policy 32 (2001), pp. 167-204

KÜHn, K-U. And Vives, X. "Information Exchange among Firms and their Impact on Competition", European Commission paper, 1995

Levy, S.M. "Should 'Vaporware' Be an Antitrust Concern?" The Antitrust Bulletin, Vol. 42 (1997), pp. 33-49

Lopatka, J.E. And Page, W.H. "Microsoft, Monopolization, and Externalities: some uses and abuses of economic theory in antitrust decision making", The Antitrust Bulletin, Vol. 40 (1995), pp. 317-370

Milgrom, P.R. "Good News and Bad News: Representation Theorems and Applications", Bell Journal of Economics Vol. 12 (1981), 380-391

Milgrom, P.R. And Roberts, J. "Relying on the Information of Interested Parties", RAND Journal of Economics Vol. 17 (1986), pp. 18-32

Okuno-Fujiwara, M., Postlewaite A. and Suzumura, K. "Strategic Information Revelation", Review of Economic Studies Vol. 57 (1990), pp. 25-47

Ordover, J.A. And Willig, R.D. "An Economic Definition of Predation: Pricing and Product Innovation", Yale Law Journal Vol. 91 (1981), pp. 8-53

Prentice, R. "Vaporware: Imaginary High-Tech Products and Real Antitrust Liability in a Post-Chicago World", Ohio State Law Journal Vol. 57 (1996), pp. 11631262

Prentice, R.A. And Langmore, J.H. "Beware of Vaporware: Product Hype and the Securities Fraud Liability of High-Tech Companies", Harvard Journal of Law and Technology Vol. 8 (1994), pp. 1-74

RAith, M. "A General Model of Information Sharing in Oligopoly", Journal of Eco- 
nomic Theory 71 (1996), pp. 260-288

Scotchmer, S. "Standing on the Shoulder of Giants: Cumulative Research and Patent Law", Journal of Economic Perspectives Vol. 5 (1991), pp. 29-41

Shapiro, C. "Exchange of Cost Information in Oligopoly", Review of Economic Studies Vol. 53 (1986), pp. 433-446

Shapiro, C. "Antitrust in Network Industries", U.S. Department of Justice Antitrust Division, Address by Carl Shapiro at January 25, 1996

Shapiro, C. and Varian, H.R. "Information Rules: A Strategic Guide to the Network Economy", Harvard Business School Press, 1999

United States vs. Microsoft Corp. Civil Action No. 94-1564, 1994-95

Verrecchia, R.E. "Essays on Disclosure", Journal of Accounting and Economics Vol. 32 (2001), pp. $97-180$

Vives, X. "Oligopoly Pricing: Old Ideas and New Tools", MIT Press, 1999

Wallace, J. and Erickson, J. "Hard Drive: Bill Gates and the Making of the Microsoft empire", Harper Business, 1992. 


\section{CESifo Working Paper Series}

(for full list see www.cesifo.de)

1393 Juan C. Conesa and Carlos Garriga, Optimal Response to a Demographic Shock, January 2005

1394 Christian Gollier, Optimal Portfolio Management for Individual Pension Plans, February 2005

1395 Ruslan Lukach, Joseph Plasmans and Peter M. Kort, Innovation Strategies in a Competitive Dynamic Setting, February 2005

1396 Gebhard Kirchgässner, (Why) Are Economists Different?, February 2005

1397 Marko Köthenbürger, Panu Poutvaara and Paola Profeta, Why are More Redistributive Social Security Systems Smaller? A Median Voter Approach, February 2005

1398 Gabrielle Demange, Free Choice of Unfunded Systems: A First Assessment, February 2005

1399 Carlos Fonseca Marinheiro, Sustainability of Portuguese Fiscal Policy in Historical Perspective, February 2005

1400 Roel M. W. J. Beetsma and Koen Vermeylen, The Effect of Monetary Unification on Public Debt and its Real Return, February 2005

1401 Frank Asche, Petter Osmundsen and Maria Sandsmark, Is It All Oil?, February 2005

1402 Giacomo Corneo, Media Capture in a Democracy: The Role of Wealth Concentration, February 2005

1403 A. Lans Bovenberg and Thijs Knaap, Ageing, Funded Pensions and the Dutch Economy, February 2005

1404 Thiess Büttner, The Incentive Effect of Fiscal Equalization Transfers on Tax Policy, February 2005

1405 Luisa Fuster, Ayşe İmrohoroğlu and Selahattin İmrohoroğlu, Personal Security Accounts and Mandatory Annuitization in a Dynastic Framework, February 2005

1406 Peter Claeys, Policy Mix and Debt Sustainability: Evidence from Fiscal Policy Rules, February 2005

1407 James M. Malcomson, Supplier Discretion over Provision: Theory and an Application to Medical Care, February 2005

1408 Thorvaldur Gylfason, Interview with Assar Lindbeck, February 2005 
1409 Christian Gollier, Some Aspects of the Economics of Catastrophe Risk Insurance, February 2005

1410 Gebhard Kirchgässner, The Weak Rationality Principle in Economics, February 2005

1411 Carlos José Fonseca Marinheiro, Has the Stability and Growth Pact Stabilised? Evidence from a Panel of 12 European Countries and Some Implications for the Reform of the Pact, February 2005

1412 Petter Osmundsen, Frank Asche, Bård Misund and Klaus Mohn, Valuation of International Oil Companies -The RoACE Era, February 2005

1413 Gil S. Epstein and Shmuel Nitzan, Lobbying and Compromise, February 2005

1414 Marcel F. M. Canoy, Jan C. van Ours and Frederick van der Ploeg, The Economics of Books, February 2005

1415 Eric A. Hanushek and Ludger Wößmann, Does Educational Tracking Affect Performance and Inequality? Differences-in-Differences Evidence across Countries, February 2005

1416 George Kapetanios and M. Hashem Pesaran, Alternative Approaches to Estimation and Inference in Large Multifactor Panels: Small Sample Results with an Application to Modelling of Asset Returns, February 2005

1417 Samuel Mühlemann, Jürg Schweri, Rainer Winkelmann and Stefan C. Wolter, A Structural Model of Demand for Apprentices. February 2005

1418 Giorgio Brunello and Lorenzo Rocco, Educational Standards in Private and Public Schools, February 2005

1419 Alex Bryson, Lorenzo Cappellari and Claudio Lucifora, Why so Unhappy? The Effects of Unionisation on Job Satisfaction, March 2005

1420 Annalisa Luporini, Relative Performance Evaluation in a Multi-Plant Firm, March 2005

1421 Giorgio Bellettini and Carlotta Berti Ceroni, When the Union Hurts the Workers: A Positive Analysis of Immigration Policy, March 2005

1422 Pieter Gautier, Michael Svarer and Coen Teulings, Marriage and the City, March 2005

1423 Ingrid Ott and Stephen J. Turnovsky, Excludable and Non-Excludable Public Inputs: Consequences for Economic Growth, March 2005

1424 Frederick van der Ploeg, Back to Keynes?, March 2005

1425 Stephane Dees, Filippo di Mauro, M. Hashem Pesaran and L. Vanessa Smith, Exploring the International Linkages of the Euro Area: a Global VAR Analysis, March 2005 
1426 Hans Pitlik, Friedrich Schneider and Harald Strotmann, Legislative Malapportionment and the Politicization of Germany's Intergovernmental Transfer System, March 2005

1427 Konstantinos Angelopoulos and Apostolis Philippopoulos, The Role of Government in Anti-Social Redistributive Activities, March 2005

1428 Ansgar Belke and Daniel Gros, Asymmetries in the Trans-Atlantic Monetary Policy Relationship: Does the ECB follow the Fed?, March 2005

1429 Sören Blomquist and Luca Micheletto, Optimal Redistributive Taxation when Government's and Agents' Preferences Differ, March 2005

1430 Olof Åslund and Peter Fredriksson, Ethnic Enclaves and Welfare Cultures - QuasiExperimental Evidence, March 2005

1431 Paul De Grauwe, Roberto Dieci and Marianna Grimaldi, Fundamental and NonFundamental Equilibria in the Foreign Exchange Market. A Behavioural Finance Framework, March 2005

1432 Peter Egger, Stefan Gruber, Mario Larch and Michael Pfaffermayr, Knowledge-Capital Meets New Economic Geography, March 2005

1433 George Economides and Apostolis Philippopoulos, Should Green Governments Give Priority to Environmental Policies over Growth-Enhancing Policies?, March 2005

1434 George W. Evans and Seppo Honkapohja, An Interview with Thomas J. Sargent, March 2005

1435 Helge Berger and Volker Nitsch, Zooming Out: The Trade Effect of the Euro in Historical Perspective, March 2005

1436 Marc-Andreas Muendler, Rational Information Choice in Financial Market Equilibrium, March 2005

1437 Martin Kolmar and Volker Meier, Intra-Generational Externalities and InterGenerational Transfers, March 2005

1438 M. Hashem Pesaran and Takashi Yamagata, Testing Slope Homogeneity in Large Panels, March 2005

1439 Gjermund Nese and Odd Rune Straume, Industry Concentration and Strategic Trade Policy in Successive Oligopoly, April 2005

1440 Tomer Blumkin and Efraim Sadka, A Case for Taxing Education, April 2005

1441 John Whalley, Globalization and Values, April 2005

1442 Denise L. Mauzerall, Babar Sultan, Namsoug Kim and David F. Bradford, Charging $\mathrm{NO}_{x}$ Emitters for Health Damages: An Exploratory Analysis, April 2005 
1443 Britta Hamburg, Mathias Hoffmann and Joachim Keller, Consumption, Wealth and Business Cycles in Germany, April 2005

1444 Kohei Daido and Hideshi Itoh, The Pygmalion Effect: An Agency Model with Reference Dependent Preferences, April 2005

1445 John Whalley, Rationality, Irrationality and Economic Cognition, April 2005

1446 Henning Bohn, The Sustainability of Fiscal Policy in the United States, April 2005

1447 Torben M. Andersen, Is there a Role for an Active Fiscal Stabilization Policy? April 2005

1448 Hans Gersbach and Hans Haller, Bargaining Power and Equilibrium Consumption, April 2005

1449 Jerome L. Stein, The Transition Economies: A NATREX Evaluation of Research, April 2005

1450 Raymond Riezman, John Whalley and Shunming Zhang, Metrics Capturing the Degree to which Individual Economies are Globalized, April 2005

1451 Romain Ranciere, Aaron Tornell and Frank Westermann, Systemic Crises and Growth, April 2005

1452 Plutarchos Sakellaris and Focco W. Vijselaar, Capital Quality Improvement and the Sources of Growth in the Euro Area, April 2005

1453 Kevin Milligan and Michael Smart, Regional Grants as Pork Barrel Politics, April 2005

1454 Panu Poutvaara and Andreas Wagener, To Draft or not to Draft? Efficiency, Generational Incidence, and Political Economy of Military Conscription, April 2005

1455 Maurice Kugler and Hillel Rapoport, Skilled Emigration, Business Networks and Foreign Direct Investment, April 2005

1456 Yin-Wong Cheung and Eiji Fujii, Cross-Country Relative Price Volatility: Effects of Market Structure, April 2005

1457 Margarita Katsimi and Thomas Moutos, Inequality and Relative Reliance on Tariffs: Theory and Evidence, April 2005

1458 Monika Bütler, Olivia Huguenin and Federica Teppa, Why Forcing People to Save for Retirement may Backfire, April 2005

1459 Jos Jansen, The Effects of Disclosure Regulation of an Innovative Firm, April 2005 